\title{
ДУХОВНО-ІНТЕЛЕКТУАЛЬНЕ НАВЧАННЯ ТА ВИХОВАННЯ В УКРАЇНІ ТА В СВІТІ
}

\author{
Я. Волкова \\ аспірантка кафедри історії педагогіки і порівняльної педагогіки \\ Харківського національного педагогічного університету імені Г. С. Сковороди
}

Стаття присвячена розгляду духовного, інтелектуального виховання та навчання в Україні. Порівнюється досвід з іншими країнами. Висвітлюються цінності, особливості та взаємозв' язок між навчанням та духовним розвитком особистості. Охарактеризовано особливості реалізації основних завдань із формування духовноінтелектуальної особистості учня. Особливу увагу приділено питанню формування в учнівської молоді духовності, як важливої якості становлення особистості.

Актуальність проблеми. У наш час дуже важко стало поєднувати такі два поняття як «духовність» та «інтелект». Економічно-політична ситуація в державі, напружені стосунки між країнами внесли негативні корективи у ці поняття.

Педагогічна наука розглядає проблему духовно-інтелектуального виховання особистості, як одну 3 провідних, адже те, як людина визначає цінності, усвідомлює свою сутність, істотно впливає на всю ії життєдіяльність, значимість духовно-моральних компонентів у навчально-виховному процесі загальноосвітньої школи. Вони залежать від культурно-історичних умов розвитку суспільства, динаміки відносин держави і церкви та надають додаткові - часом запрограмовані - способи самореалізації дитини в культурно-освітньому просторі країни.

Аналіз наукових джерел засвідчує наявність доволі великої різноманітності теоретичних уявлень про духовність, та інтелектуальне навчання. Розглядаючи наукові праці філософів, психологів, педагогів зустрічаємо різні трактування поняття духовності. Наприклад, у М. Бердяєва [2] духовність - це найвища якість, цінність, найвище досягнення самої людини, оскільки найвища мета — не економічна, не соціальна, а духовна.

Е. Помиткін описує духовність як «специфічно людську рису, що виявляється в багатстві духовного світу особистості, iї ерудиції, розвинених інтелектуальних і емоційних запитах, моральності» [6, с. 28], a I. Бех [1] зазначає, що духовність передбачає вихід за межі егоїстичних інтересів, особистої користі й зосередженість на моральній культурі людства.

С. Яремчук [7] знаходить спільне між духовністю та працею, спрямованою до саморозвитку, що допомагає людині стати Людиною і зберігає їі людяність.

С. Ярмусь [8] вважає, що до духовності входить свідома активність людського духу, яка підносить людину до ідеалу добра, - до того, що її облагороджує.

О. Вишневський [4] наголошує та тому, що духовність є найвищим щаблем абсолютних цінностей, пов’язує iii зі шляхом людини до Бога, іiі зорієнтованістю до дотримання в житті Божих заповідей.

Духовність, за А. Богуш [3], — це своєрідний інтелектуально-чуттєвий, емоційний стан особистості, що виявляється в позитивній поведінці й діяльності людини та характеризує цілісність її як особистості.

Отже, спираючись на думки вчених, занотовуємо, що духовність - це основа культури людства, це спадщина українського народу, яка нагадує нам про традиції, доброту, щирість, людяність нашої нації. Тільки завдяки нашим нащадкам, ми маємо можливість удосконалювати нашу духовність через освіту.

Виклад основного матеріалу. Поняття «виховання» в педагогічній літературі застосовується в широкому та вузькому значенні. Виховання в широкому значенні трактується як освіта, навчання, процес формування особистості й підготовки їі до активної участі у виробничому, суспільному та культурному житті. Формування світогляду, морального обличчя, розвиток смаку, фізичний розвиток — це більш вузьке значення розглядуваної дефініції.

В Законі Україні «Про Освіту» зазначено, що освіта є основою інтелектуального, духовного, фізичного і культурного розвитку особистості, ïi успішної соціалізації, економічного добробуту, запорукою розвитку суспільства, об'єднаного спільними цінностями і культурою, та держави.

Метою освіти є всебічний розвиток людини як особистості та найвищої цінності суспільства, иіi талантів, інтелектуальних, творчих і фізичних здібностей, формування цінностей і необхідних для успішної самореалізації компетентностей, виховання відповідальних громадян, які здатні до свідомого суспільного вибору та спрямування своєї діяльності на користь іншим людям і суспільству, збагачення на цій основі інтелектуального, економічного, творчого, культурного потенціалу Українського народу, підвищення освітнього рівня громадян задля забезпечення сталого розвитку України та ії європейського вибору.

Цей Закон регулює суспільні відносини, що виникають у процесі реалізації конституційного права людини на освіту, прав та обов' язків фізичних і юридичних осіб, які беруть участь у реалізації цього права, а також визначає компетенцію державних органів та органів місцевого самоврядування у сфері освіти [9]. 
Отже, освіта - $є$ основою інтелектуального, культурного, духовного, соціального, економічного розвитку суспільства і держави. Розбудова національної системи освіти перш за все грунтується на ідеях народності. У змісті виховання особистості дитини пріоритетними є ідеї свободи, рівності, національної та особистої гідності, шанування родинних зв’ язків, формування працелюбності, взаємодопомоги і самодисципліни, заощадливості, потреби здобувати знання і вміння у всіх видах праці, ставлення до свого життя і життя інших людей як до найвищої цінності.

Таким чином у виховному процесі центральними є виховання загальнолюдських цінностей особистості (доброти, милосердя, толерантності тощо), стимулювання їі внутрішніх сил до саморозвитку і самовиховання. В Україні розпочали свою діяльність вальдорфські школи. 3 1995р. вони працюють в Одесі (2 школи), Донецьку, Дніпропетровську. Існують центри вальдорфської ініціативи в Харкові, Львові, Києві, Івано-Франківську та інших містах. Вальдорфська педагогіка сприяє насамперед духовному розвитку дитини, а потім - інтелектуальному. Провідна педагогічна ідея підпорядкована втіленню в життя людського ідеалу: Доброти, Краси, Істини. Таким чином, сьогодення вимагає підвищення рівня духовності не тільки учительства як передового загону національної інтелігенції, а й усієї нації, відродити іiї найкращі просвітницькі традиції.

Спираючись на телепередачі Володимира Познера [10], присвячені фінській системі освіти, їх історії, доцільно буде продекламувати аспекти фінського духовно-інтелектуального навчання та виховання нації. Найпоширеніші думки про найкращу освіту Фінляндії — це не міф. Духовність цього народу почала відроджуватися з 1809 року, ще з часів царя Олександра І. Історичний досвід доводить, що нація, яка прагнула кращого майбутнього своїм дітям, має державу, що піклується про них та реформи освіти, що дозволяє дітям ставати тими, ким вони хочуть бути, при цьому залишаючись щасливими. Кожна дитина навчається у своєму темпі. Навчання не асоціюється 3 величезними витратами коштів батьків. Кожен учень має те, що йому знадобиться, апріорі. Кожен отримує задоволення від навчання, бо держава сворює усі необхідні умови для цього. Це робить людей чесними між собою та перед державою. Духовність грунтується на взаємопідтримці. Як бачимо, у Фінській системі виховання чітко відзначено ієрархію ціннісних орієнтирів. Пріоритетними є родинні та громадянські. Успіх духовно-морального виховання дітей в дусі традиційних цінностей залежить від узгодженої взаємодії (часто - єдності) важливих соціальних інститутів: родини, школи (в особі педагога-вихователя і змісту загального навчання), громадських просвітницьких установ. У Фінляндії намагаються поєднати гуманістичні цінності з новими науковими знаннями.

Варто зазначити, що у виховній взаємодії у Фінляндії важливим є принцип світоглядного плюралізму, сприйняття існування особливої різної культури й традицій у вихованні дітей, толерантності, що допомагає уникати завантаженості, одномірності духовно-інтелектуального виховання і навчання.

Можна з гідністю зазначити про те, що спільним є підходи до організації духовно-інтелектуального навчання і виховання в Україні і Фінляндії. У ході наукового пошуку з'ясовано, що для цих країн спільним $\epsilon$ робота освітніх установ у такому ключі: відображаючи суперечливий характер розвитку держави і суспільства, педагоги прагнуть формувати в учнів базові цінності, які в своїй сукупності можуть бути об’єднані в групи традиційних духовних цінностей (планетарність, народність), етнічних (збереження і зміцнення родинних традицій і звичаїв), естетичних (варіювалися в різних соціальних прошарках суспільства), педагогічних цінностей (гідна освіта і моральне виховання підростаючого покоління, розвиток дитини, гуманізація освітнього процесу). Пріоритетними серед них є охоронні цінності морального християнського ідеалу духовності людини; громадянськості в широкому їі розумінні; національно-патріотичних відчуттів; верховенства сім’ї, посередництвом якої забезпечують взаємозв’язок світського і релігійного світогляду людей.

Слушно зауважено у дослідженні В.Ворожбіт про те, що родинні цінності є базисом духовно-інтелектуального виховання як в Україні, та у світі в цілому. Ці цінності впливають на здійснення життєвого відбору духовних і моральних законів існування сім’ї, які демонструють ставлення до довкілля. Відомо, що батьки не можуть скерувати життя і діяльність дитини повною мірою, вони можуть лише передати моральні орієнтири, які визначатимуть життєдіяльність дитини у дорослішанні. Родинне виховання сприяє становленню духовності особистості дитини через передачу досвіду попередніх поколінь, вироблення звички шанування предків, уміння взаємопідтримки і допомоги. У такий спосіб формується цінність єдності сім’ї, отже - громади, нації в цілому. Не можна обійти увагою той факт, що під впливом ціннісних орієнтацій сім’ї на особистісному рівні дитини відбувається відбір інших духовних цінностей [5].

Цікавим видається критерій правильності духовно-інтелектуального виховання дітей, а саме: тривалість навчання, коли учні утримують довільно увагу і проявляють зосередженість.

Секрет щасливого і здорового шлюбу полягає в терпінні й спільне захоплення обох подружжя. У фінської жінки завжди було багато терпіння, і сім’ї в Фінляндії були завжди дуже великі. Чоловік у Фінляндії є головою сім’ї і основним годувальником, так як йому необхідно утримувати сім'ю і дітей.

Проте в даний час, як і в багатьох інших країнах у Фінляндії спостерігається зниження кількості дітей в сім’ї, і сім’ї вже не бувають такими великими. Сімейні традиції збереглися не у всіх сім’ях, адже саме вони служать зміцненням всередині сімейних відносин і всієї родини в цілому. 
У Фінляндії часто зустрічаються цивільні шлюби, в яких подружжя може прожити дуже багато років і тільки потім поєднуватися законним шлюбом. Середній вік для чоловіків, які бажають вступити в шлюб десь близько 30 років, жінки починають думати про сімейне життя на пару років раніше.

У цьому віці вже приходить розуміння того, що необхідно створити той осередок суспільства, в якому буде тепло і затишно, куди вони можуть повернутися після важкого трудового дня і відпочити.

У Фінляндії сім'ї нечисленні, практично в кожній сім’ї $є$ по одній дитині, менше 30 відсотків сімей мають двох і трьох дітей. Фінляндія стала першою країною, де визнано, були рівноправність жінок і чоловіків, і саме тут з'явилася перша жінка-президент.

Найголовніше в сім’ї, це щоб були спільні інтереси, почуття єдності подружжя та дітей, взаємоповага і любов. Головне в сім'ї - це діти та їх виховання, їм потрібно віддавати багато сил, терпіння i, звичайно ж, кохання. Без любові неможливо виховати доброї і розумної людини.

Всі батьки бажають, щоб їх дитина отримала чудову освіту, створила сім’ю, мала високе положення в суспільстві і була шанованою людиною. Фінські батьки прекрасно це розуміють $\mathrm{i}$, знаючи про те, що на освіту і виховання дітей необхідні фінансові кошти, не прагнуть до того, щоб мати велике потомство.

У Фінляндії дуже велика відмінність фермерських сімей від міських сімей, в яких все-таки переважає прагнення до матеріального блага. У фермерських сім'ях діти разом з батьками долучаються до роботи 3 дитинства, при цьому виробляється фізична сила і здоров'я дітей набагато міцніше, ніж у дітей в міських сім'ях, до того ж вони отримують менше психологічних травм.

Як і в будь-якій іншій країні, у Фінляндії найбільшу відповідальність за виховання дітей несуть жінки, і саме жінки беруть відпустку по догляду за дитиною. У Фінляндії чоловіки також багато часу приділяють вихованню дітей, і частіше саме вони гуляють 3 дітьми, грають та займаються з ними спортом.

Базою духовно-інтелектуального навчання і виховання у фінській освітній системі можна назвати принцип довіри. Так, у Фінляндії немає перевірок та методичних консультацій. Для країни діє єдина система освіти, i, відповідно, однакові рекомендації для вчителів. Способи навчання і виховної взаємодії обирає сам педагог. Довіра до учнів проявляється у визнанні права кожного учня самостійно обрати, що для нього корисніше. Наприклад, якщо на уроці вмикають документальний фільм, а дитині він не цікавий, школяр може замість перегляду стрічки читати книгу. Важливою складовою фінської освіти $є$ добровільність. Вчиться той, хто хоче вчитися. Якщо дитина не зацікавлена в освіті або немає до цього здібностей, ії навчання закінчується після 9 класу. Увагу учня скерують на якусь нескладну практичну професію та не будуть завалювати незадовільними оцінками. Адже не всім будувати літаки, хтось має і професійно керувати автобусами. У цьому фіни і бачать завдання середньої школи: виявити, чи йти дитині вчитися далі в ліцей, чи корисніше піти у професійне училище. Варто відзначити, що обидва шляхи у Фінляндії однаково високо цінуються.

Щоб допомогти дитині зорієнтуватися в майбутніх професіях, в школах працює спеціаліст із профорієнтації, який за допомогою тестів та бесід координує навчання школяра та орієнтує його на певні види діяльності.

Отже, унікальність кожного народу лежить в його історії. В його прагненнях. В його досягненнях і традиціях. Культурно-національні традиції українського народу визначали багатовимірність, поліаспектність самого поняття духовно-морального виховання, його цілісно-синтетичної характеристики. Освіта є необхідною для кожного народу, як фундамент духовності особистості. Від того, як буде відбуватися інтелектуальне збагачення, буде залежати духовний розвиток людини, чи буде воно супроводжуватися конкуренцією чи матеріальними турботами, чи буде цілеспрямовано рухатися у правильному напрямку, це залежить від держави та системи освіти. Ціннісні орієнтири - індивідуалізації і рівності, гуманізації і високої міри довіри в освіті, визнання необхідності опори на родинні цінності у духовно-інтелектуальному вихованні і навчанні - прослідковуються в досвіді педагогічної співпраці як українських, так і фінських педагогів.

Для України і Фінляндії спільним $є$ традиційне використання виховного потенціалу правильно організованого процесу навчання, суспільно корисної праці; вільно вибраної справи (часто — фізичної, «мускульної», ручної праці); шефство старших учнів над молодшими; колективні ігри, культура спілкування з людьми, тваринами, природою; усвідомлений спосіб життя в родині.

\section{Література}

1. Бех І. Д. Виховання особистості: сходження до духовності. К. : Либідь, 2006. 272 с.

2. Бердяев Н. А. Философия свободного духа. М. : Республика, 1994. 480 с.

3. Богуш А. М. Дефініції «духовність» і «моральність» в аспекті національного виховання в Україні // Морально-духовний розвиток особистості в сучасних умовах : збірник наукових праць. К., 2000. Кн.1. С.18-23.

4. Вишневський О. Теоретичні основи сучасної української педагогіки : навчальний посібник. Вид 3-є, доопрац. і доп. К. : Знання, 2008. 566 c. 
5. Ворожбіт В. В. Напрями родинного духовно-морального виховання у другій половині ХІХ століття : зб. матеріалів Всеукр. наук.-практ. конф. «Перспективні наукові досягнення — 2011», 17 лют. 2011 р. Миколаїв : Нац. ун-т кораблебудування ім. адмірала Макарова, 2011. С. 64-65.

6. Помиткін Е. О. Психологія духовного розвитку особистості : монографія. К. : Наш час, 2007.280 с.

7. Яремчук С. В. Проблема духовності в процесі професійної підготовки майбутніх педагогів : збірник наукових праць Інституту психології ім. Г. С. Костюка Національної АПН України / за ред. С. Д. Максименка. К., 2012. T. XIV. Ч. 1. C. 397-404.

8. Ярмусь С. Досвід віри українця : вибрані твори / упорядн. А. Колодний. К. : Світ знань, 2002. 512 с.

9. https://zakon.rada.gov.ua/laws/show/2145-19.

10. https://www.1tv.ru/shows/puteshestviya-urganta-i-poznera/samye-samye-samye/samye-samye-samye-10-seriya-finlyandiyasamye-upornye-mezhdu-shveciey-i-rossiey-priklyucheniya-poznera-i-urganta-v-skandinavii-i-finlyandii. 